\title{
Designing a Model for Processes Reengineering through Applying Agility Enterprise Architecture Framework and Priority of its Implementation Phases
}

\author{
Dr. Mohammad Hossain Moshref Javadi \\ (Corresponding author) \\ Faculty member of Management department, University of Isfahan, Isfahan, Iran \\ Hezarjarib St., 81746-73441, Isfahan, Iran \\ E-mail: MHMJ20032003@yahoo.com \\ Maedeh Rabbanimehr \\ Graduate Student of Industrial Management, University of Isfahan, Iran \\ Hezarjarib St., 81746-73441, Isfahan, Iran \\ E-mail: m.rabbanimehr@yahoo.com \\ Majid Foruzan \\ Department of Management, Payame Noor University, Isfahan, Iran \\ E-mail: MajidForuzan@yahoo.com
}

Accepted: November 05, 2012 Published: December 22, 2012

Doi:10.5296/ijhrs.v2i4.2934

URL: http://dx.doi.org/10.5296/ijhrs.v2i4.2934

\begin{abstract}
In the current condition of the world and with regards to the world competition, organizational existence has become the most important problem of the managers. The success secret of current organizations depends on setting their ultimate goals and objectives outside of the organization. In another word, in a safe organization, goal is to serve its customers. In this regard, the meaning of agility is to reach customer's wants and desires by wastages elimination in all sections of the organization. Therefore, sometimes an organizations in order to reach such objectives need to implement fundamental changes.

Agility enterprise architecture is an architectural framework for organizational reengineering in designing, developing, integrating and performing a agility organization in applying systems engineering methods. With regards to the discussion of information technology and systems engineering in today's organizations which is considered important. In this article, it is tried to study processes reengineering with the use of agility enterprise architectural reengineering framework with focusing on competitive intelligence and its practical phases. Eventually, reasons for importance of agility enterprise architecture, summary and results along with propositions will be explained. The research results indicated that the proposed framework has some benefits which among the most important ones are: Improvement quality in organization, delivering just in time of goods, enhancing customer satisfaction, wastages elimination and as a results decreasing costs. Overall, the benefits gained from this model can create stability in the world competition.
\end{abstract}




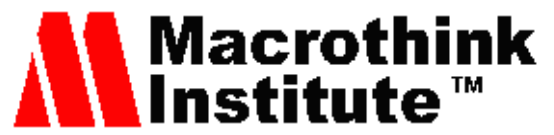

Key words: Processes reengineering, enterprise architecture, agility production, competitive intelligence, AHP

\section{Introduction}

Because of the global changes in economic, globalization of the markets, change in customers needs and competition increase, new approaches for compatibility with environment changes has developed and it is rapidly expanding. Reengineering with process-based and with fundamental changes in the organization, replaces activities with no added values, with new processes. In such case, organizational energy is focused on real works and creative values, which will result in high productivity along with speed increase, quality improvement, service improvement cost price decrease $(1,7)$. From the second half of 1990, enterprise architecture as a comprehensive and strategic alternative in developing and maintenance of information network and as tool for Business process Reengineering (BPR) has strongly been paid attention to (11). Information architecture which is information technology enterprise architecture as briefly is known as enterprise architecture, prior of being a mean for creating information networking, it is an approach for providing an enterprise framework for coordinating of the total activities and information technology elements inside of an enterprise.

Enterprise architecture can be simulated as jungle of models in witch without a guidance map, going through the journey is almost impossible (15). Global competition has shifted enterprises towards: titles such as: quantity, flexibility, delivery time and speed and has caused production enterprises to focus their strategies on the based of agility production (a comprehensive business system technique which combines: Total quality management (TQM), Just in time (JIT), total productivity maintenance (TPM)). The objective of agility production, reduction of wastages in process, production and delivering of high - quality goods, low- inventory level and processes with high effectively. A study in the late 1990 shows that more than 90 percent of managers of enterprises have introduced agility production as a critical for production with high performance(6). For implementation of such improvement methods in processes, organizations for shifting from the current situation to agility - base view - point and Focusing on competitive intelligence confronted with challenges in enterprise architecture. Such shifting will end changes in processes, material flow, information systems, enterprise hierarchy and material management (2). Competitive intelligence is the art of finding, collecting and saving data and making them available for all employees to support shaping the future of organization and safeguarding existing status against competitive threats.

Objective of this article is to study reengineering of processes with the use of enterprise architecture, process reengineering which is to be compatible with agility principles and condition and competitive intelligence and as well as setting priorities for practical phases

In this regard, process reengineering, enterprise architecture and agility concept, AHP and competitive intelligence will each be explained. Subsequently, similarities and possibilities of implementing them in framework, setting priorities for practical phases , benefits gained from presented model and eventually, summary and proportions will be stated. 


\section{2- Processes Reengineering}

Processes Reengineering concept as a mean of enterprise performance improvement was proposed for first time by Massachusette Institute of technology during 1990's. The first theorist who introduced such concept was Meakel Hamer that added reengineering concept to the science of management in a magazine (12). Since that time, multiple definition for reengineering has been presented, which in general could be said that, reengineering is defined as fundamental and principally rethinking of processes for achieving incredible success in sensitive criteria such as: quality and service rate as speed. Today, if there exist one common idea concerning corporation is that all of them including governments have to redefine themselves from the beginning. The present role-playing fundamental forces are more clever than forgetting the future. The new enterprises are those that are designed to get advantage from today and tomorrow's world. They are not such organizations that are transferred to a noble preliminary period which is not related to today (1).

In the recent years, with regard to science development especially in the area of information technology, enterprises have to compromise with changes and with the new technologies. Today, in the new world, compromising with information technology is considered one of the ways of change, in which, tools such as: counseling corporations, organizational soft wares, enterprise architecture, internet, intranet, knowledge management and .... are used in this path(7).

Implementing reengineering consist of steps such as understanding of enterprise architecture, measuring and permanent following of performance, applying shift management, and providing central organizational support and reengineering project management to access results(11).

Figure 1 shows steps of reengineering in the enterprises.

At it is perceived, reengineering of processes is done two major phases: study of the current situation and desired situation. In the current situation, all of the conditions, document and record approvals, major and minor processes and rules that governs enterprise are studied and following the study of the results, forecasting continuation of the current situation will be performed. Afterwards, if the condition with regard to the current documents is not desirable to continue, concerning provided documents, at this stage, process study would move the next stage, which is study of the desired situation. After setting the concept and organization mission, the strength and weakness of the organization, identifying the roots of untidy, collecting information, they all are studied to get red of untidies and identifying the wants and desires which eventually the corporation will reach strength and improvement. In the total steps, information systems and enterprise architecture play important roles in the current processes shifts and in the enterprise changes, because of the rapid advancement and day to day progress in this area $(1,7)$. 


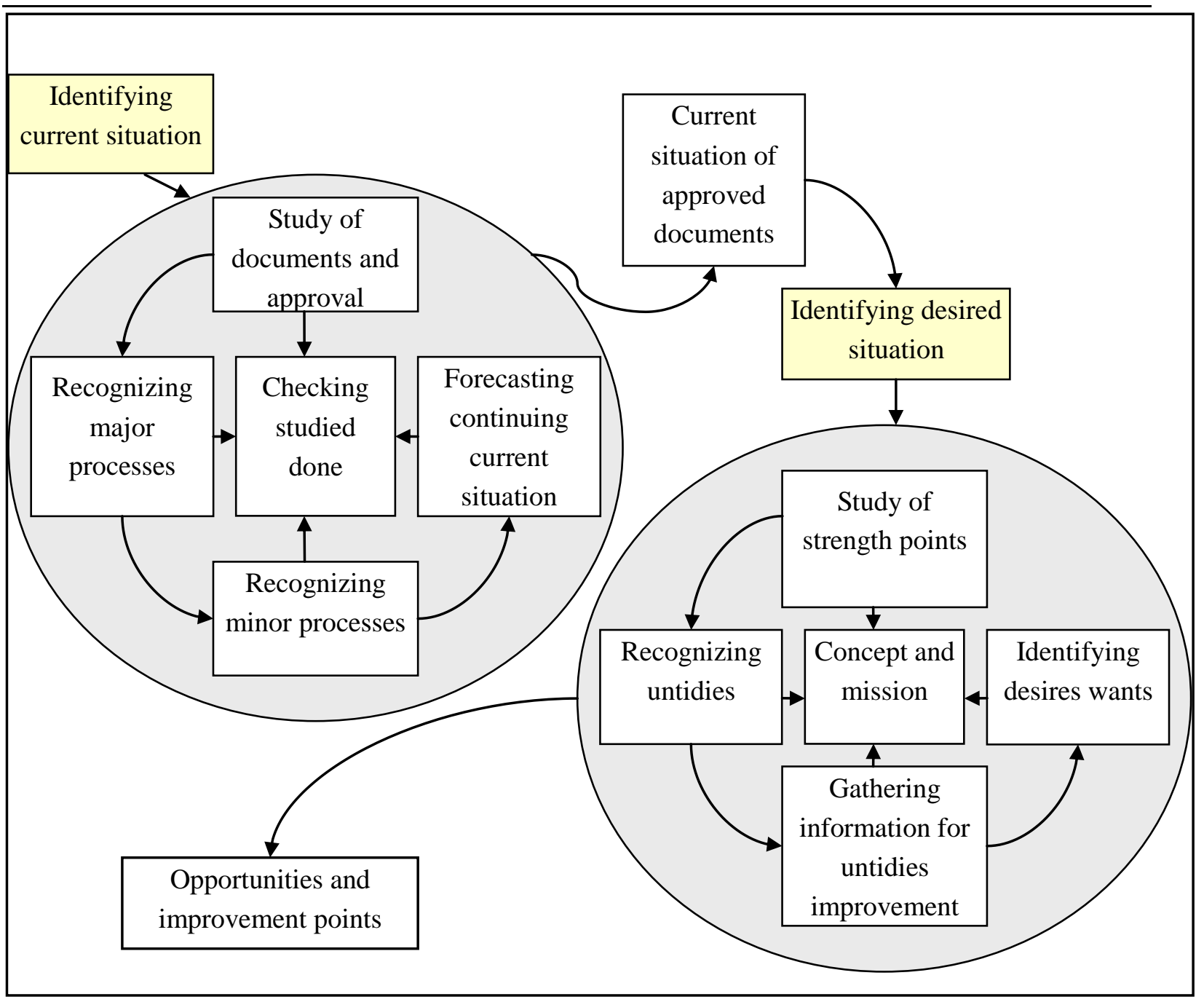

Figure1: necessary steps for applying reengineering in enterprise

\section{3- Enterprise architecture concept}

Defence and energy departments of the United States were leaders of enterprise architectural research. In this country, the act relating to enterprise architectural was approved and defined as: Promoting or maintaining current technology and accessing information technology towards the objectives. Afterward, they started projects in the areas of information architecture (3). Architecture, is not an unknown term. This word is mostly used in the civil sciences. Architecture is a combination of science, art and experience which in majors such as civil has several thousands years experience (15). Zacman has defined "enterprise architecture" as of the following: The set of descriptive models related to an organization in a way so to be compatible with the needs of management (quality) produced, which in its useable period, it is capable maintaining (changeable) (10).

Enterprise architecture is paid attention in three layers such as guideline layer, missionary layer and communication and information technology layer which are defined as of the following: 
1. Guideline layer: This layer is responsible for policy making, determination of long term goals, values, policies, guidelines and also organizational immense planning and to define perspectives and also criteria of efficiency evaluations and effectiveness of lower layer.

2. Missionary layer: This layer involves organizational missionary sections which has various levels like top level management, middle level management and operation itself.

3. Communication and information technology layer: This layer specially includes all communication information technologies which organizations use them in line with implementation of missionary layer activities (9).

In condition when speaking of enterprise architecture one or all three layers may be considered. In this article, guideline layer and missionary layer subjects are more considered.

\section{4- Enterprise architecture process}

In figure 2 below enterprise architecture processes can be seen briefly

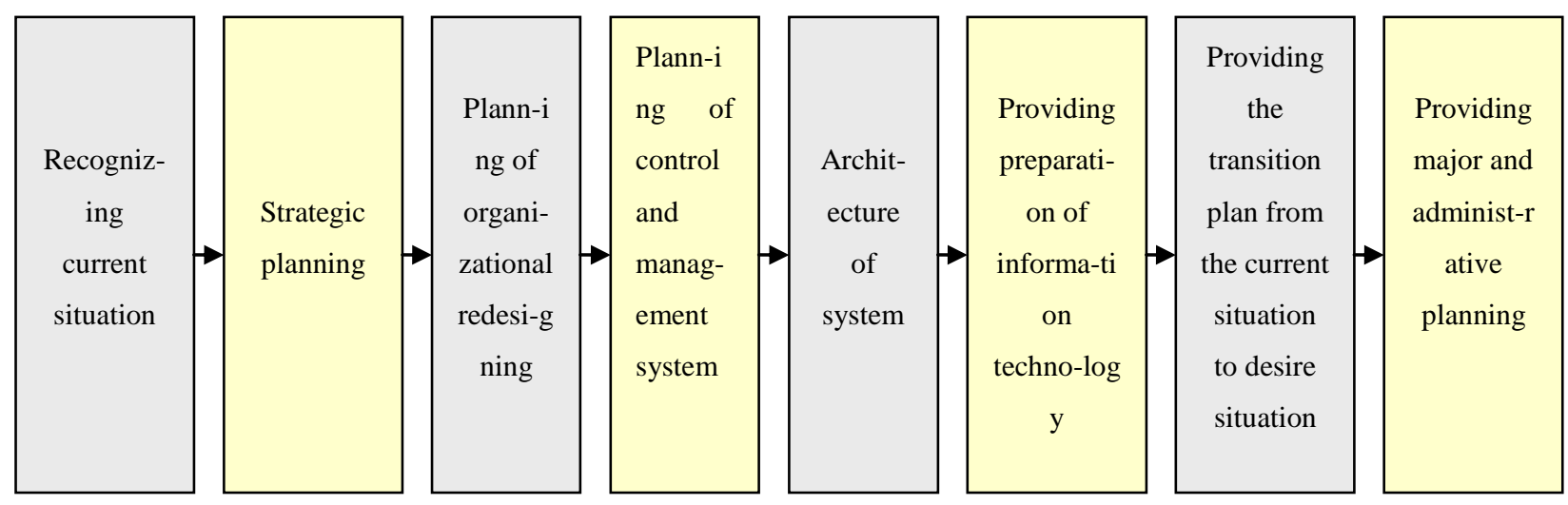

Figure 2: enterprise architecture process

\section{5- Definition of agility}

Agility refers to successful identification of competition principles (speed, flexibility, innovation, quality and profitability), consolidating resources and conducting appropriate measures in a knowledge area characterized with rapid changes leading to providing product and services for the customers. Agility aims profitability, market share and wining customers in competitive markets. Agility is the ability of development under the circumstance of nonstop and unexpected changes for those organizations which offer a variety of products at the same time without requiring reorganization or ceasing the production.

Ganasekran (1998, 2001) and Sharp and his colleagues (1999) have respectively introduced seven and ten enabling factor of agile production. Here we indicate ten enabling factors as following:

1- Virtual business

2- E-commerce

3- Rapid production of initial sample 
4- Enabling

5- Continuous improvement

6- Flexible and multi-skilled employees

7- Teamwork

8- Simultaneous engineering

9- Risk and change management

10- Integrated business/production/product information system

\section{6- Competitive intelligence}

There a variety of definitions available for competitive intelligence. Here we refer to the definition introduced by Association of Competitive Intelligence Experts which defines the competitive intelligence as:

an organized and moral plan for collecting, analyzing and managing external data which can affect the organization's plans, decisions and operations.

The concept of competitive intelligence classified into four main categories:

1- Business (marketing) intelligence

2- Competitors-oriented intelligence

3- Technology and technical intelligence

4- Strategic and social intelligence (e.g. laws, financial and tax laws, political issues, ...) (Gilad, 2011).

Table 1. Competitive intelligence roles and responsibilities

\begin{tabular}{|l|l|}
\hline Role & Responsibilities \\
\hline $\begin{array}{l}\text { Competitive benchmarking } \\
\text { Implantation of rapid alert system }\end{array}$ & $\begin{array}{l}\text { A watchtower to trace the key environment changes } \\
\text { which affect the organization future. } \\
\text { Information management and distribution } \\
\text { Guidance for blind points }\end{array}$ \\
$\begin{array}{l}\text { Training and enabling the employees } \\
\text { Supporting business strategic }\end{array}$ & $\begin{array}{l}\text { Active participation as the organization guideline } \\
\text { for determining the decision-making requirements }\end{array}$ \\
$\begin{array}{l}\text { decision-making } \\
\text { Converting the data and information into } \\
\text { usable knowledge }\end{array}$ & $\begin{array}{l}\text { into the organization } \\
\text { Reassuring performing business intelligence not }\end{array}$ \\
& being sourced from non-moral and illegal activities. \\
& Reassuring enabling the entire organization \\
\hline
\end{tabular}


Source: Kahanar, 1997

\section{7- The process of competitive intelligence}

According to Kahaner (1996) definition, competitive intelligence is an integrated process and consists of four phases; planning and leadership, data collection, analysis and distribution. Each phase is explained in detail below:

1- Planning and leadership: The process starts by defining and conducting the act of intelligence. This is important that the requirements of user are fully realized since it is a prerequisite to success. The time frame plays an important role in this phase.

2- Data collection: This phase include collecting data to be used in intelligence system. Different authors have introduced three types of data:

2-1) White data(unlocked data): The data which comes from free sources such as those available in publications, magazines, ....

2-2) Grey data: The data which are of private source such as the commercial documents kept in companies.

3-1) black date: The data whose access is restricted but might become available by computer data theft or wiretapping. Almost $80 \%$ of collected data are white and $15 \%$ are grey.

3- Analysis: It is the core of competitive intelligence; it means to convert the unrelated data into intelligence. Analysis holds the virtues of both art and science.

4- Distribution: The analyzer in this phase brings in the possible solutions and distributes them among the users.

Moreover to above-mentioned four phases, Fald (1995), has added up the fifth phase as secure saving and delivering of information. (Franco et al., 2011 ;Chris, 1999; Johns et al., 2010)

\section{8- AHP}

AHP is a structured technique for organizing and analyzing complex decisions. It was developed by Thomas L. Saaty in the 1970s and has been extensively studied and refined since then. It has particular application in group decision making, and is used around the world in a wide variety of decision situations, in fields such as government, business, industry, healthcare, and education. Rather than prescribing a "correct" decision, the AHP helps decision makers find one that best suits their goal and their understanding of the problem (Seungbum and Ross, 2012).

AHP is based on the hierarchy tree principal. A sample of hierarchy tree has been shown in Fig. 3 (Khamkanya et al., 2012) 


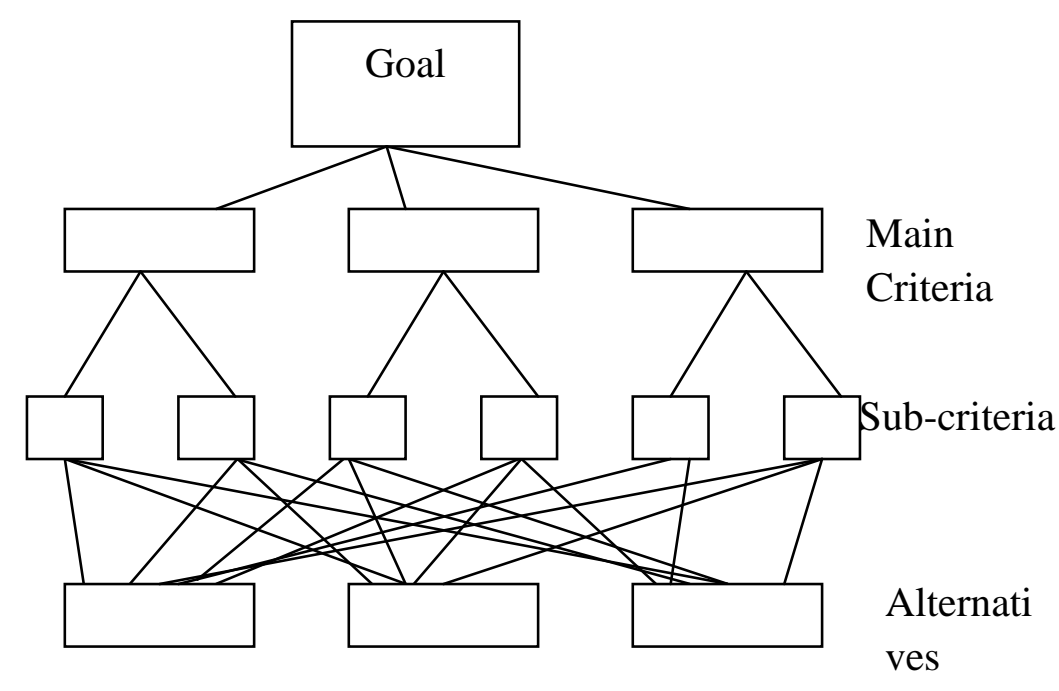

Fig. 3. A sample of hierarchy tree (Vinodh et al.,2012)

Men fail to realize a problem entirely unless divide it into smaller problems and make pair comparison by using certain criteria to determine which one will be better. The results then will be input into various decision-making models to create a better perception of the whole system (Hambali et al., 2009).

To set priorities, preferential values for pair comparison are of importance which are shown in below table (Zaim et al.,2012).

Table 2. preferential values for pair comparison

\begin{tabular}{|c|l|}
\hline $\begin{array}{c}\text { Intensity of } \\
\text { importance }\end{array}$ & \multicolumn{1}{|c|}{ Definition } \\
\hline 1 & Equal importance \\
\hline 3 & $\begin{array}{l}\text { Weak importance of one over } \\
\text { other }\end{array}$ \\
\hline 5 & Essential or strong important \\
\hline 7 & Demonstrated importance \\
\hline 9 & Absolute importance \\
\hline $2,4,6,8$ & $\begin{array}{l}\text { Intermediate values between } \\
\text { the two adjacent judgments }\end{array}$ \\
\hline
\end{tabular}

\section{9- Common aspects of reengineering, enterprise architecture and agility manufacturing and competitive intelligence}

For the use of agility enterprise architecture reengineering framework in order to processes reengineering and competitive intelligence it should examine the aspects of similarity between these four approaches:

Aspects of similarity: 
1. The aim of all four approaches is to increase productivity and improvement quality in organization.

2. The bases of these four, is to shift from existing conditions to desired conditions: This is shown in picture 1 and 2 and about agility thought as explained, its aim is wastages elimination and reform of usage model, and as a result enhancing customer satisfaction after fundamental change in existing conditions to desired condition in organization .

3. Attention to strategic view as their primary principle.

4. Pay attention to customers opinions: specially in agility thought. It is very important to pay attention to customers wills and products based on customer orders. In processes reengineering, prerequisite of feeling for change is paying attention to customer opinions, In enterprise architecture also the goal is to attract customer satisfaction.

5. Change management: This phase is one of the fundamental principles of reengineering and this concept make important part in use of agility manufacturing and enterprise architecture.

6. Attention to management and control system. Developing change and reconstruction for reaching commercial superiority is impossible without management and control system which compares current with desired situation. This is considered in every three approaches.

7. Attention to communications in organization:

Any change in organization is not possible without communication. In enterprise architecture, this factor is considered in all of three layers, especial in strategic and missionary layer, The possibility of performance and enter to technology layer is not possible without coordination and communication between people, also without establishing safe communication in organization will not fulfill the agility production and processes reengineering and competitive intelligence that is required cooperation of organizational personnel, communication with customers and beneficiaries.

With regard to mentioned aspects of similarity, it is possible to use these four approaches in the shape of a framework .

\section{0-Agility enterprise architecture: A methodology for processes reengineering}

Processes reengineering with the use of agility enterprise architecture framework consist of three phases that is showed in picture 4 (A combination of figures \# 1,2,3) which has been shown completely as of the following:

1. Strategic planning phase

2. Obtaining and integrating phase

3. The phase of performing processes reengineering plan

1. Strategic planning phase: 


\section{MlMacrothink}

The strategic planning examine the necessary operational characteristics in order to compare with agility paradigm along with agility viewpoint. Strategic plan is founded on three basic elements: Ultra structure, agility operation and personnel change management.

2. Obtaining and integrating phase:

This phase is created in order to integrate with the environment and conditions for successful change in organization. The steps of this phase consist of:

- Needs category: lists of needs related with criteria such as: delivery timing and identifying cultural needs necessary for IT integration.

- Acquired plan (obtaining primary concepts of proposed framework): Acquired plan is a strategy for administration of reengineering elements includes of planning manager/ busying, manufacturing, manufacturing management and designing.

- Integration plan: Integration plan is an approach to make desirable communication lines. Integrated processes approach and product development is a commercial tool in order to help achieving effective and useful goals.

- Change management: The second phase is in need of change management that its heart is communication.

3. The phase of performing the excellence plan (shifting from current to desired situation): Successful performing of reengineering with proposed framework needs continued improvement, measuring of advancement level, leadership, creativity and organizing. Performing agility enterprise architecture is possible if planning management, cellular production processes, selecting the best sources, administrative support, organization personnel efforts are along with excellence organization. So a good executive plan depends on exact time- plan, performance matrix, engineering changes, management risks, cost and seller selection.

In usage of any these stage, agility thought principles are used in which steps, the agility principles are applied and necessary steps necessary for reengineering based on proposed framework are as of the following:

1. Conceptual plan: Definition of productive strategy based on agility viewpoint, . analysis of product, applying workshop production which means production based on customer order, benchmarking(A comparison between organization and competitors on the basis of collecting and analysis of data and modeling from them)applying principles and factors of agility production.

2. Primary plan: Simulation that is based on needs and conceptual plan proceed to simulation of conditions in order to use LEA framework, human resource planning, facilities designing and cellular design that is a kind of machinery composition based on agility concept and use of agility principles.

3. Detailed plan: equipment planning, flow analysis, simulation workshop production, benchmarking and agility principles. 


\section{Macrothink Institute ${ }^{\mathrm{TM}}$}

4. Carrying out (performance): In this stage, the results of three former factors are performed, equipment selection, preparing of IT provided plan, education, test, benchmarking and agility principles are steps of this stage.

5. Operation: operative stage needs to use leadership, creativity, planning and control, continued important, stability, change management and agility principles. 


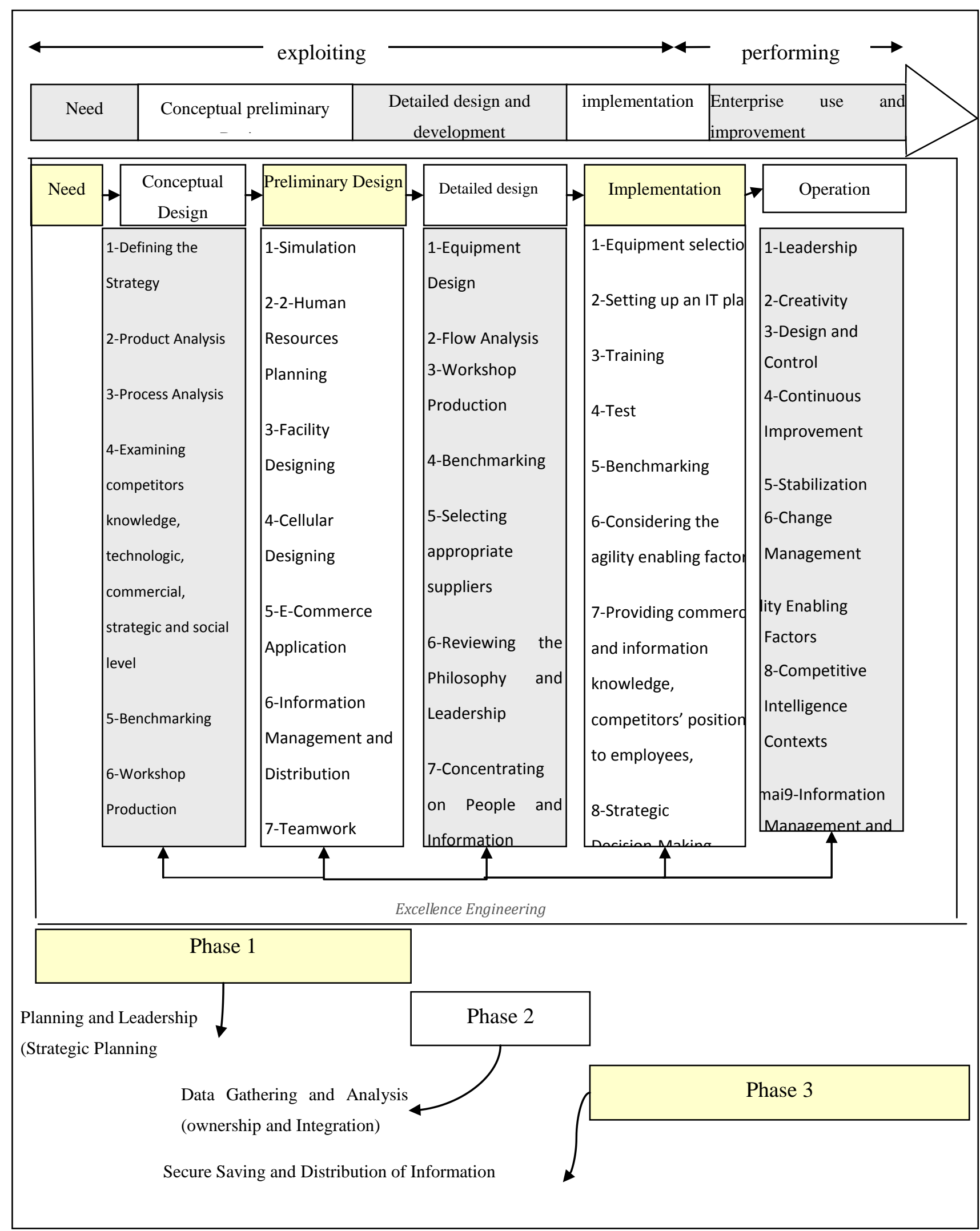

Figure 4: AEA framework for processes reengineering

Studying figure 4 from down to up after description of basic phases, attention is paied to 


\section{Macrothink Institute"}

agility reengineering cycle. This cycle includes feel to change, developing conceptual plan, making primary plan, detailed plan, performance and operation. Totally, this framework consist of two stages, obtaining and exploiting which has shown on the top of figure 4. obtaining stage includes need, primary-conceptual plan, extension of design and performing and exploiting stage of performing and organizational improvement(2).

\section{1- Setting priority for executive phases}

In order to set the executive phases of proposed model based on their priority, the below AHP pair comparison table has been used:

Table 3. proioritization for implementation phase of model.

\begin{tabular}{|c|c|c|c|c|c|c|c|c|c|c|c|}
\hline & $\begin{array}{l}\text { Equipment } \\
\text { Selection }\end{array}$ & $\begin{array}{l}\text { Setting } \\
\text { up } \\
\text { IT } \\
\text { plan }\end{array}$ & Training & Test & Benchmarking & $\begin{array}{l}\text { Considering } \\
\text { the agility } \\
\text { enabling } \\
\text { factors }\end{array}$ & $\begin{array}{l}\text { Enlightening } \\
\text { /Informing }\end{array}$ & $\begin{array}{l}\text { Making } \\
\text { strategic } \\
\text { business } \\
\text { decisions }\end{array}$ & $\begin{array}{l}\text { Converting } \\
\text { the data } \\
\text { into } \\
\text { exploitable } \\
\text { information }\end{array}$ & $\begin{array}{l}\text { A } \\
\text { guidance } \\
\text { to blind } \\
\text { points }\end{array}$ & $\begin{array}{l}\text { Relative } \\
\text { weight }\end{array}$ \\
\hline $\begin{array}{l}\text { Equipment } \\
\text { Selection }\end{array}$ & 1 & 2 & 2 & 3 & 3 & $1 / 4$ & $1 / 3$ & $1 / 2$ & $1 / 2$ & 2 & .0849 \\
\hline $\begin{array}{l}\text { Setting up } \\
\text { IT plan }\end{array}$ & & 1 & $1 / 2$ & 2 & 2 & $1 / 5$ & $1 / 2$ & $1 / 3$ & $1 / 2$ & 2 & .0562 \\
\hline Training & & & 1 & 2 & 3 & $1 / 3$ & $1 / 2$ & $1 / 2$ & $1 / 2$ & 2 & .0744 \\
\hline Test & & & & 1 & 2 & $1 / 8$ & $1 / 3$ & $1 / 4$ & $1 / 3$ & $1 / 2$ & .0365 \\
\hline Benchmarking & & & & & 1 & $1 / 9$ & $1 / 3$ & $1 / 4$ & $1 / 3$ & $1 / 2$ & .0291 \\
\hline $\begin{array}{l}\text { Considering } \\
\text { the agility } \\
\text { enabling } \\
\text { factors }\end{array}$ & & & & & & 1 & 3 & 2 & 2 & 8 & .2800 \\
\hline $\begin{array}{l}\text { Enlightening } \\
\text { /Informing }\end{array}$ & & & & & & & 1 & $1 / 2$ & $1 / 2$ & 3 & .1120 \\
\hline $\begin{array}{l}\text { Making } \\
\text { strategic } \\
\text { business } \\
\text { decisions } \\
\end{array}$ & & & & & & & & 1 & $1 / 2$ & 4 & .1307 \\
\hline $\begin{array}{l}\text { Converting } \\
\text { the data into } \\
\text { exploitable } \\
\text { information }\end{array}$ & & & & & & & & & 1 & 2 & .1430 \\
\hline $\begin{array}{l}\text { A guidance to } \\
\text { blind points }\end{array}$ & & & & & & & & & & 1 & .0450 \\
\hline
\end{tabular}

According to this table, the higher the relative weight of the phase, the higher the priority. 


\section{Ml Macrothink \\ International Journal of Human Resource Studies \\ ISSN 2162-3058 \\ 2012, Vol. 2, No. 4}

The results of the table 3 are as following:

\begin{tabular}{|c|c|c|c|c|c|c|c|c|c|c|}
\hline Priority & 1 & 2 & 3 & 4 & 5 & 6 & 7 & 8 & 9 & 10 \\
\hline Phase & $\begin{array}{l}\text { Considering } \\
\text { the agility } \\
\text { enabling } \\
\text { factors }\end{array}$ & $\begin{array}{l}\text { Converting the } \\
\text { data into } \\
\text { exploitable } \\
\text { information }\end{array}$ & $\begin{array}{l}\text { Making } \\
\text { strategic } \\
\text { business } \\
\text { decisions }\end{array}$ & $\begin{array}{l}\text { Enlightening } \\
\text { /Informing }\end{array}$ & $\begin{array}{l}\text { Equipment } \\
\text { Selection }\end{array}$ & Training & Setting up IT plan & $\begin{array}{l}\text { A } \\
\text { guidance } \\
\text { to blind } \\
\text { points }\end{array}$ & Test & $\begin{array}{l}\text { Benchmar } \\
\text { king }\end{array}$ \\
\hline
\end{tabular}

It is during executive phase when the outcomes of previous phases materialize and the organization meets its planning goals. Therefore, in this paper, after designing an executive model, ten executive steps of it have been prioritized.

As seen in above table, to apply the proposed model, considering the agility enabling factors comes in first priority. That is, the organization should first reassure about the agility prerequisites such as training flexible employees, creating task teams, business integrated information system, etc in executive phase. To apply such a model, converting the data into exploitable information is in next priority. Gather a lot of data without converting them into exploitable information will in vain for the organization. The next priority is belongs to strategic business decision-making because the executive phase of long term decisions and plans will help. In executive phase, the organization must enjoy competitive intelligence which requires commercial knowledge, information on competitors' positions, technical technology knowledge and social strategic knowledge (such as knowledge about laws, financial, taxation and political issues, etc.). Without appropriate selection, no production take place and all previous concepts are useless so its place in fifth priority. Training the employees and setting up an IT plan respectively with 0.0744 and 0.0562 are placed in sixth and seventh priorities. In case there is any ambiguity and indistinctness during executive phase, it is necessary to provide required training for employees. This is has been set in eighth priority. After this step the, first stage of doing the task is initiated by test the method. In case during or after test there are some points that are incompatible to the plan, those points are identified. Later, efforts are made by benchmarking the successful organizations to improve the organization capability in application of this model.

\section{2- Reasons for importance of agility enterprise architecture}

Implementing agility enterprise architecture principles help organization for quality improvement, delivery on time, customer satisfaction and wastages elimination that causes to decrease in operational costs and increase in capital rate .

Generally, its advantages are as follows:

- Quality improvement: The organizations that use agility enterprise architecture, in average, they decrease their faulty up to twenty percent and increase their quality by up to eighty percent.

- Customer satisfaction: Delivery on time and produce based on customer need, which causes an increase on customer satisfaction in an organizations with agility enterprise architecture framework. 
- Increase in productivity: agility technique help organizations to use less resources and increase their products and in average be witness of thirty percent increase in productivity.

- Decrease in operational costs: quality improvement, increase in productivity, and customer satisfaction which are results of this framework, which all causes to decrease costs of operation in the organization.

- Decrease in inventory during the manufacturing flow through production by customer orders.

- Elimination wastage in organization

- Decrease in time of delivery products $(6,15,8)$.

\section{3- Conclusion and suggestions (Recommendations)}

In this article, it was tried to use concepts such as, enterprise architecture and agility production and competitive intelligence to study processes reengineering in the organization, and briefly the objective was examination of reengineering using agility engineering architecture framework with focusing on competitive intelligence and its practical phases. In order to reach such goal, concepts like reengineering, enterprise architecture, agility production, competitive intelligence and AHP were explained and it contained by similarity aspects of the expressed cases, agility enterprise architecture framework for reengineering and the benefits and reasons of its importance. As in the part of similarity aspects and also in the agility enterprise architecture part, you see a framework for reengineering, reaching to this aim and direction shown in figure 4.Given framework has some benefits such as quality improvement increase in productivity, decrease in delivery time, enhancing customer satisfaction and decreasing costs. As a conclusion of this article using some elements are necessary for carrying out the agility enterprise architecture successfully that include:

1. Specification of enterprise architecture goals that causes basic development of performance plan.

2. Agility education and organizational communication that is necessary for empowering organizational personnel toward moving to a agility - based duties with focusing on competitive intelligence.

3. Organizational development: There are some suggestions for future research like following:

- Continuation of research about architectural frameworks for using them in the agility architectural plans.

- Studying of new enterprise architecture frameworks are used in system engineering processes.

- Development of mentioned design.

- Benchmarking of proposed framework performance. 
- Design and draw a path for those organizations that use agility enterprise architecture.

\section{References}

1. Akhavan.P, Jafari.M \& Ali-Ahmadi.A. Exploring the interdependency between reengineering and information technology by developing a conceptual model. Business Process Management Journal Vol. 12 No. 4, 2006, pp. 517-534.

2. Dennis F.X. A agility architecture for transforming the aerospace maintenance, repair and overhaul(MRO) enterprise ,International Journal of Productivity and Performance Management Vol. 54 No. 8, 2005,PP.623-644.

3. Fathian, M. and Mahdavi, H., Principles of information technology management, fifth Ed. Tehran: Science and Industry university of Iran, 1387.

4. Gurumurthy.A. and Kodali.R. Application of benchmarking for assessing the agility manufacturing implementation, Benchmarking: An International Journal, Vol. 16 No. 2, 2009 pp. 274-308.

5. Jorgensen. B. Emmitt.S. Lost in transition: the transfer of agility manufacturing to construction, Engineering, Construction and Architectural Management, Vol. 15 No. 4, 2008, pp. 383-398.

6. Kennedy .F. A. \& Widener.S. K. A control framework: Insights from evidence on agility accounting, Manage, Account, Res, 2008, pp153-164.

7. Peng S. C. and Land.C. Implementing reengineering using information technology Business Process Management, Journal, Vol. 5 No. 4, 1999, pp.311-324.

8. Pham D.T. and Pham P.T.N. Integrated production machines and systems - beyond agility manufacturing, Journal of Manufacturing Technology Management Vol. 19 No. 6, 2008,PP.695-711.

9. Samadi, A.,Intraduction to enterprise architecture, first Ed. Tehran: Informative Superior concil,1384.

10. Shams, F., Enterprise architecture based concepts, Takfa management, $\# 3,2^{\text {nd }}$ year, p 11 , 1383.

11. Subhas C. Misra, U. K. and Vinod K. Modelling strategic actor relationships for risk management in organizations undergoing business process reengineering due to information systems adoption, Business Process Management Journal .Vol. 14 No. 1,2008, pp. $65-84$.

12. Sulaiman A. Process redesign: reengineering core process at computer department - a case of SWCC, Business Process Management Journal, Vol. 15 No. 2, 2009, PP.183-200.

13. Taj. Sh. \& Berro.L, Application of constrained management and agility manufacturing in developing best practices for productivity improvement in an auto-assembly plant, 
International Journal of Productivity and Performance Management Vol. 55 No. 3/4, 2006, pp. 332-345.

14. Taj.Sh., Agility manufacturing performance in China: assessment of 65 manufacturing plants, Journal of Manufacturing Technology Management Vol. 19 No. 2, 2008, pp. 217-234.

15. Zargarnetag, M, Study of methods of enterprise information technology architecture, MS.Dissertation, Beheshti university, 1385. 